\title{
THE ANTARCTIC PACK ICE
}

\author{
$B y$ H. F. P. HERDMAN \\ Chief Scientific Officer to the "Discovery" Committee, London
}

\begin{abstract}
Observations on the distribution and movement of the pack ice around Antarctica. These are based mainly on the work of the "Discovery" Committee's ships between 1925 and 1939, but also include observations from the pelagic whaling fleet for the years $1930-36$. The seasonal advance and retreat of the pack ice are considered in detail and information is given of conditions at the ice edge throughout the year. The movement, or drift, of the pack ice is thought to be closely connected with the surface waters around the Antarctic Continent and a brief account of these currents is included. Some outstanding problems are mentioned in connexion with future research and attention is drawn to the need for air reconnaissance.
\end{abstract}

Zusammenfassung. Die Beobachtungen beruhen hauptsächlich auf der Arbeit der Naturwissenschaftler auf den Schiffen des "Discovery Committee" zwischen r 925 und 1939, sie umfassen jedoch auch Beobachtungen der Walfischfangflotte auf hoher See in den Jahren 1930-36. Der jahreszeitliche Vorstoss und Rückgang des Packeises wird ausführlich behandelt, und Auskunft über die Beschaffenheit der Eisgrenze wird durch das ganze Jahr hindurch wird ausführlich behandelt, und Auskunft über die Beschaffenheit der Eisgrenze wird durch das ganze Jummenhang mit gegeben. Es wird angenommen, dass die Stromung oder das Tin kurzer Bericht dieser Strömungen ist in dem Artikel inbegriffen. Einige wichtige Probleme werden fur zukünftige Forschungen erwähnt. Es wird auf die Notwendigkeit für Erkundung vom Flugzeug aufmerksam gemacht.

Much has been written on the subject of Antarctica and on the work of the various expeditions which have visited the continent and the surrounding oceans since 1775 when the first circumnavigation of the Antarctic was made by James Cook. Little, however, has been published on the subject of the distribution and movement of the pack ice which surrounds the continent for the greater part of the year and which is the decisive factor in making any approach to the land, or indeed in planning any scientific work in Antarctic waters. The formation and break-up of the pack ice had been studied in a few localities, but it was not until the advent of pelagic whaling in these waters, some 15 or 16 years ago, that the problem of the general distribution of the Antarctic pack ice began seriously to be considered.

In 1934 Hansen ${ }^{1}$ published a short paper, illustrated by a series of charts showing the positions of the ice edge at different times on the southern whaling grounds. These charts covered the seasons $1929-30$ to $1933-34$. They were an extremely valuable record of the distribution of pack ice in these four Antarctic summers; but they covered only the area between $40^{\circ} \mathrm{W}$. and $110^{\circ} \mathrm{E}$. and the period from October to March. Subsequently Hansen ${ }^{2}$ compiled an Atlas over Antarktis og Sydishavet which showed the approximate mean positions of the ice edge in November, December, January and March in all except the Pacific sector, and in January and March in the Pacific sector also. This atlas is presumably based on abundant material so far as the whaling grounds are concerned, but there are few observations in other regions.

In 1940 a paper on the limits of the pack ice in the Southern Ocean was published in the Discovery Reports. ${ }^{3}$ This paper was based mainly on observations made by the "Discovery" Committee's ships, but also included a considerable amount of data from whaling ships supplied by Captain Hansen. In certain areas these were more numerous than those of the Committee's ships, but the latter were more widely distributed in time and space, and, what is more important, included a number of winter observations. Miscellaneous sources providéd a small number of additional observations which helped to fill some of the gaps, but not all accessible data were used since in some areas there was more than sufficient information for inclusion on charts of the scale found most satisfactory for this paper. 


\section{SEASONAL DISTRIBUTION OF THE PACK ICE}

\section{General Features}

The pack ice, which generally has a well-defined northern boundary, extends furthest north in late winter and spring. Its edge lies approximately in the same position from July to October. In certain areas local conditions, such as cold southerly or relatively warm northerly gales, may cause a temporary displacement of the boundary, but with the return of more stable conditions the ice edge, in winter and early spring, resumes its average position.

During the late summer the pack ice melts and begins to break up, the ice edge gradually retreating towards the continent. The southern limit is generally reached in February or March, although parts of the coasts of Antarctica have been found clear of ice as early as January. No signs of pack, for instance, were seen off Adélie Land when the Discovery II approached this coast in mid-January $193^{8}$, nor did she meet any on her south-easterly course from lower latitudes. With the exception of the Pacific sector, and probably the east coast of Graham Land, it is likely that nearly all parts of the fixed shelf ice or continental coast are free from pack ice from time to time during the late summer. In the Pacific sector, at any rate between the meridians of $75^{\circ}$ and $140^{\circ} \mathrm{W}$., the ice seems heavier and more stagnant. As yet no ship has been able to penetrate to the land, although several attempts have been made to do so. In the Weddell Sea ice conditions are far from simple and will be discussed later.

\section{Advance and Retreat}

The retreat and advance of the ice edge, and hence of the main body of pack ice, are best illustrated by maps. It will, perhaps, be sufficient here to consider the map of the retreat in summer, and Fig. I (p. ${ }^{8} 5^{8}$ ) shows the apparent mean positions of the ice edge for this season. ${ }^{3}$ It is important, however, to remember that on any given date the latitude of the ice edge varies considerably from year to year. Therefore it must be emphasized that the mean positions shown here are only an average. It should also be noted that whereas the diagram shows the ice edge as an even line, this is far from being its real shape. However sharp the actual line of demarcation may be, it follows a tortuous course, with deep bays and promontories which may extend for many miles from the main body of the pack.

Summer months. September and October show little retreat of the ice edge, but in November there is a definite move to the south. The most rapid break-up or melting appears to take place between December and January, after which the retreat is again gradual. It is of interest to note that in the Atlantic sector in December there is generally a broad belt of pack ice stretching from the South Shetlands to about $30^{\circ} \mathrm{E}$., with open water to the south. In January and February this belt retreats to the west and reaches a minimum in early March, but it seldom disappears. The presence of this tongue of pack ice is due to the very cold surface water flowing away to the east from the Weddell Sea. Conditions are thus maintained in comparatively low latitudes which mitigate-if they do not destroy - the chances of the melting and break-up of a large body of ice. Owing to the very heavy nature of this Weddell Sea pack ice, there is difficulty in obtaining observations by ship to the south and west of this tongue in early summer and even the approximate width is not known. Nor is it possible to state when open water to the south can reasonably be expected. Nevertheless, in the summer of $1914^{-1} 5$ the Endurance worked her way through a belt of ice 800 miles wide, at the eastern side of the Weddell Sea, to find open water off Coats Land in $72^{\circ} \mathrm{S}$. early in January. This, however, was in the Weddell Sea itself, and although it is possibie that farther to the east the pack will neither be so heavy nor so closely packed, penetration by sea in early summer will probably be possible only in certain years, and then only in the most 


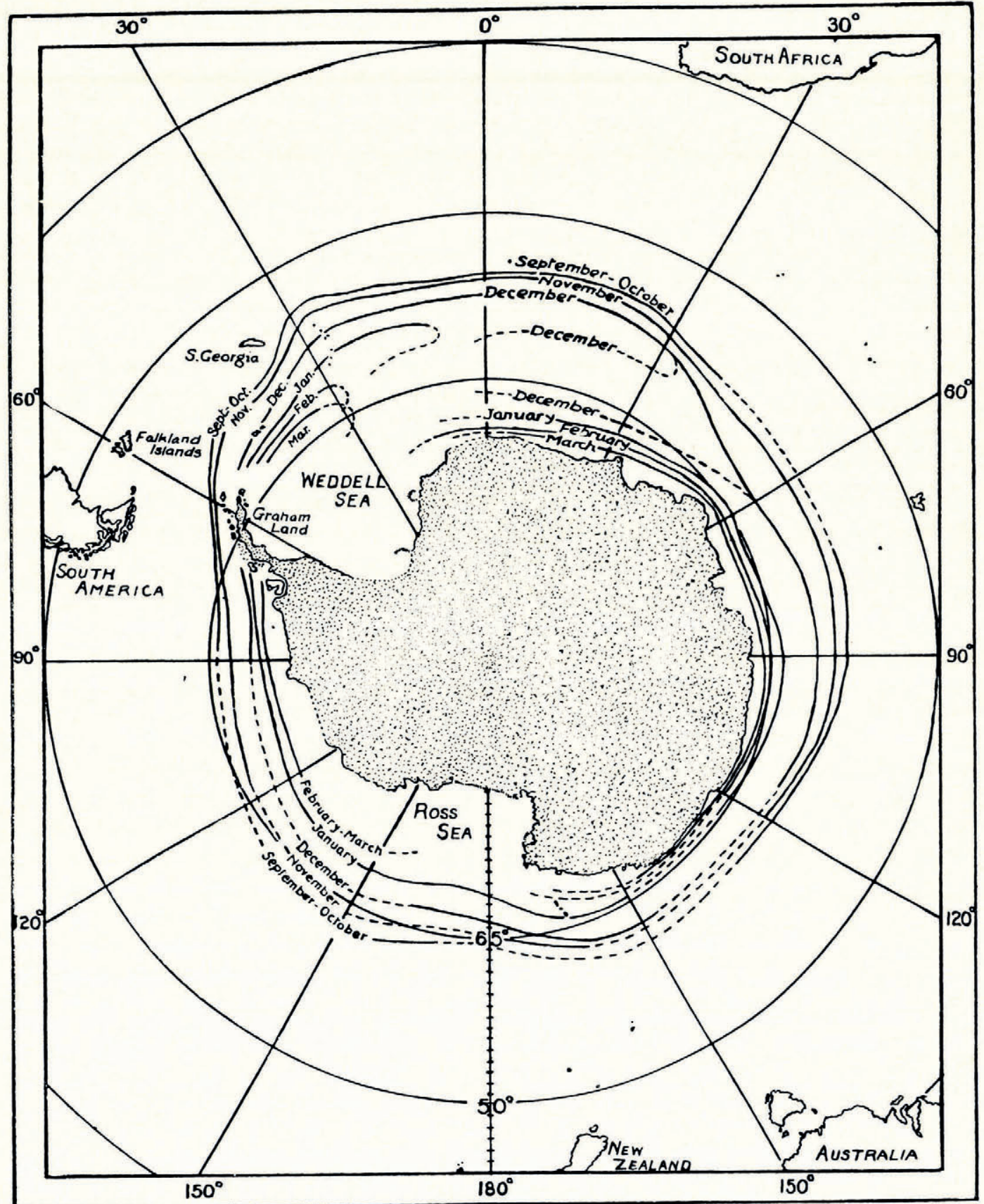

Fig. I. Apparent mean positions of the ice edge in the summer months. After Mackintosh and Herdman, Discovery Reports, Vol. 19 
favourable weather. In order to obtain definite information on the width of the Weddell Sea ice tongue at the western side of the Atlantic sector and the extent of the open water to the south, reconnaissance by air will be necessary. Although the diagram for the summer months (Fig. I) shows only the northern edge of the pack ice in the Ross Sea, it has been established for a great many years that in mid- to late summer there is open water south of the belt of pack ice which stretches across the mouth of the sea. Due in part to its wide extent and in part to the bottom configuration, there is a much less complicated current system here than in the Weddell Sea. In fact, the influence of the Ross Sea surface water extends only for a short distance along the coast towards Adélie Land. In consequence this belt of ice appears to break up and melt in the normal way. It will perhaps be of interest to give some figures obtained here in the Discovery II in I 936 . Between January $7^{\text {th }}$ and $14^{\text {th }}$ of that year, the ship pushed south approximately on the 18 oth meridian through 400 miles of almost solid pack ice. The ice was entered in $66^{\circ} 48^{\prime} \mathrm{S}$. and cleared in $73^{\circ} 23^{\prime} \mathrm{S}$. From this position there was clear water to the Ross Shelf Ice. On her return to the north fourteen days later, the southern edge of the ice belt still lay in approximately the same latitude, but the width was reduced to 150 miles. In other words, 250 miles of pack, on the northern side of the belt, had disappeared in just over three weeks. In the Pacific sector there is little retreat in summer, for reasons not at the moment fully understood. In the Australian sector it is likely that the coasts of the continent are free from pack ice in the later part of most summers.

Winter months. Although isolated reports have been made of the sea freezing over in high latitudes in late January and in February, these areas were small and the ice almost certainly melted before the general freeze-up commenced in the Weddell and Ross Seas. This begins in late March or early April, and once started the growth of the ice edge towards the north is fairly rapid until June, when the rate of advance slows down. The maximum distance of the ice edge from the continent is reached in September or October. Unfortunately there are few data for the midwinter months. The whales, and consequently the whalers, have migrated north. Nevertheless, some winter observations have been made by the Discovery $I I$ and these are sufficient to give a general indication of the limits of the winter advance. They indicate that at its maximum extent the northern limit of the pack ice lies some 900-1000 miles from Antarctica, in the region of the South Sandwich Islands. They also show that probably the largest area of the Southern Ocean which is covered by ice is in the Atlantic and western Indian Ocean sectors. Like the persistence of pack ice here in summer, this is attributable to the eastward flow of cold surface water from the Weddell Sea.

\section{Formation of Pack Ice}

At this stage it might be as well to consider the way in which pack ice forms. Examination of the surface isotherms shows that in early April a wide belt of cold surface water, with a temperature of less than $-\mathbf{I}^{\circ} \mathrm{C}$., surrounds the Antarctic continent. With still conditions and low air temperatures - often of the order of $-12^{\circ}$ to $-15^{\circ}$ C. - rapid freezing of the sea begins, and if these conditions persist, a solid sheet of thin ice soon forms (see Fig. 2, p. 172). In the open ocean, however, still conditions for any appreciable time are the exception. Although there may be a temporary absence of wind there is usually an underlying swell which rocks the newly formed ice into the shape of pancakes. In the low temperatures of autumn these pancakes grow rapidly to a fair size under the influence of wind, sea and snow (see Fig. 3, p. 172). As winter comes on with more precipitation, the pancakes become large floes. Although no definite information is at present available, it seems likely that in winter and early spring pack ice completely surrounds the Antarctic continent, reaching out to the limits for these months already determined from seaward. Proof of this, however, must remain lacking until long-range reconnaissance by air can be made at this time of year. Nevertheless, in view of the low sea temperatures prevailing far north of 
Antarctica in March and April, it seems unlikely that any area of measurable size remains entirely free from ice.

It is interesting perhaps to note here that Wordie 4 in his observations on the natural history of pack ice in the Weddell Sea states that the formation of pancake ice can also take place during the melting and decay of pack ice, although the occurrence is rare. This statement has been confirmed by our own observations.

So far it has been assumed that pack ice forms only in the open sea, but although this is probably true in higher latitudes, there are almost certainly areas where a complete break-up in summer does not occur. This is the case, for instance, in the coldest part of the Weddell Sea current and in the Pacific sector. The floes which remain are loosely packed and sheets of new ice form easily in the leads and pools of open water.

\section{Conditions at the Ice Edge}

Conditions at the edge of the pack ice, especially in regard to the type of ice, vary considerably according to the time of year and locality. In late autumn and winter the ice edge often consists of sludge and pancake ice which merge gradually into the larger floes. In spring and summer small floes and brash ice are commonly met with and the outer fringe of the main pack is generally more open in character. These conditions, however, can also vary greatly with latitude. For instance, conditions change rapidly in the Atlantic sector. Here, as we have already seen, the pack stretches far north in winter, extending well into the region of the westerly winds and the almost permanent westerly swell of these latitudes. It seems that the relatively warmer northerly winds can disperse the sludge and even new pancake ice over a considerable distance. In consequence at times there may be an apparent retreat of the ice edge; but a period of cold southerly winds over water of a very low temperature will soon result in the formation of more new ice and a rapid advance of the ice edge. In 1938 , during a series of cruises to the south and west of Cape Town, the Discovery II found that on the meridian of Greenwich the ice edge was in almost the same position in July, September and December. In August, however, the ice edge was 100 miles south of this mean position and in November 50 miles north of it. The position of the ice edge in August is of particular interest, for throughout the whole of the distance south beyond the line of the edge in the previous month, the surface temperature was steady at $-\mathbf{r} \cdot 6^{\circ} \mathrm{C}$. Some sludge ice was seen, but the main body of pack was not reached until the latitude of $57^{\circ} 18^{\prime} \mathrm{S}$.

In the eastern Pacific sector, where the ice edge at any time of year lies in a much higher latitude, the winds are easterly and cold, and the pack at all times lies south of the zone of the westerly winds. There is little advance or retreat of the ice edge throughout the year, with the result that the outer fringe of the pack is more stable, and, in consequence, more tightly packed (see Fig. 4, p. 173). It is possible that surface temperatures may provide one reason for the stagnant conditions prevalent in this sector. Here the $0^{\circ} \mathrm{C}$. isotherm, when compared with other sectors, shows little movement throughout the year. This may in part be caused by the stagnant ice conditions, but it is probable that the absence of a strong surface current is the cause both of the stagnant ice conditions and the lack of movement in the isotherms.

\section{Movement or Drift of the Pack Ice}

The predominant influence on the movement or drift of the Antarctic pack ice is the wind; not so much perhaps from the direct effect on the floes themselves, but from the part played by the surface currents engendered by the prevailing winds. A shift of wind can cause local alterations in the drift of a body of pack ice, but it would appear that the main body of pack continues to move in the general direction of the surface current. These surface currents have been described in detail by Deacon ${ }^{6}$ in his comprehensive paper on the hydrology of the Southern Ocean. Since 
I hope to show that the movement of surface water has a considerable influence on the pack ice, it is desirable here to give a brief summary of his remarks. Simply it may be stated that the principal movements of the Antarctic surface water are towards the east in latitudes north of $65^{\circ} \mathrm{S}$. ; towards the west further south, and a general northward movement, stronger in some meridians than others, throughout the whole of the zone. There are two chief causes for this movement. The eastward and westward currents appear to be caused primarily by the effect of the prevailing winds. The northward movement, although partly effected by the wind, seems to be due mainly to the influence of the cold Antarctic climate on the density distribution. Space does not permit a detailed description of how this current system is set up or the reasons for deducing the directions of flow. The general effect, however, appears to be that in the low air temperatures of winter the pack ice tends to bind closely round the continent, whereas in summer the warmer climate facilitates its dispersal towards the north.

Apart from the question of its movement, the extent or distribution of the pack ice around Antarctica appears to be related to the range of the surface current flowing westward round the coasts of the continent. In these circumstances it is perhaps advisable to give some details of the East Wind Drift, as this current is called, and to note some of its effects on the pack ice.

Surrounding the Antarctic continent at all times of year, in the region of the westerly winds, is the West Wind Drift. Between the southern limit of this (in approximately $65^{\circ} \mathrm{S}$.) and Antarctica, is a drift in the opposite direction. This latter current is practically circumpolar, being interrupted only where its path is obstructed by Graham Land. It is found again to the west of Graham Land, but the observations made during the drift of the Belgica, when beset in the ice in $1898-99$, show that the surface-water movements in the southern part of the Bellingshausen Sea are very variable. The resultant drift, however, was to the west at the rate of 0.9 miles a day. West of Peter I Øya the westerly current is only found south of $70^{\circ} \mathrm{S}$., but north of the Ross Sea it expands to a much greater range, the northern boundary reaching $65^{\circ} \mathrm{S}$. in places. In the Ross Sea the current sets westward along the edge of the Ross Barrier (the northern Ross Shelf Ice) at about $\mathrm{I}$ to 3 knots, and then northward along the western shore. The drift of the Aurora in 1915-16 shows plainly the path of the water flowing out of the sea round Cape Adare, between the Balleny Islands and Oates Land and then away to the north-west. North of $65^{\circ} 30^{\prime} \mathrm{S}$. the direction of the Aurora's drift altered to the north-east, indicating the beginning of the region of westerly winds. The average rate of drift was 2.8 miles a day in the main direction of movement. Further west the current has been observed north of King George V Land and Adélie Land, and there is little doubt that it extends along the whole of the Antarctic coast south of Australia. It must, however, be confined to a very narrow coastal region, since in this sector the Antarctic coast reaches north almost to the region of the westerly winds. The observations made by the Gauss show that between $80^{\circ}$ and $90^{\circ} \mathrm{E}$. the westerly current is again confined to a narrow strip and a drift of $12-13$ miles a day was observed by the Discovery $I I$ in the neighbourhood of the coast between $60^{\circ}$ and $70^{\circ} \mathrm{E}$. Observations in summer off Kemp Land and Enderby Land indicate a drift of about 7 miles a day. South of Cape Town the coasts of the continent lie further south and the boundary of the westerly current spreads north. In the eastern part of the South Atlantic Ocean, however, observations show that the boundary between easterly and westerly currents is not so well defined. The easterly current is well marked north of $60^{\circ}-65^{\circ} \mathrm{S}$., and the westerly current near the continent. The intermediate area, although proved by the upwelling of deep water to be a divergence region, appears to be one of irregular movements. Similar conditions exist across the Atlantic sector as far as the Weddell Sea, where the westerly current meets the Graham Land coast and is deflected to the north. A good indication of the path taken here by the westward flowing water is shown by the drift of the Endurance (and later, the ice-camp) in $1915-16$, and of the Deutschland in 1912. After being beset the Endurance drifter to the west between $77^{\circ}$ 
and $76^{\circ} \mathrm{S}$., then north-west as far as $74^{\circ} \mathrm{S}$. and, finally, the drift of the ship (and the ice-camp) was north-north-west or north. The Deutschland, beset roo-1 50 miles further from the Graham Land coast, drifted north-west as far as $72^{\circ} \mathrm{S}$., northwards between $72^{\circ}$ and $65 \frac{1}{2}^{\circ} \mathrm{S}$., eastwards for about 120 miles between $65^{\frac{1}{2}}$ and $65^{\circ} \mathrm{S}$. and then generally to the north. The line of drift, however, during these later stages was very complicated.

Observations made by the Deutschland have been interpreted by Brennecke ${ }^{7}$ to show that the movement of the ice was caused solely by the prevailing winds. However, as Wordie in his study of the Weddell Sea pack has remarked, this does not fully explain the easterly movement in $65 \frac{1}{2}^{\circ}-$ $65^{\circ} \mathrm{S}$. followed by a resumption of the northerly drift. Wordie's paper was written before the publication of Brennecke's conclusions, but his remark that $65 \frac{1}{2}^{\circ} \mathrm{S}$. is a high latitude in which to expect westerly winds in the Weddell Sea, especially in September, appears to hold good even after an examination of Brennecke's figures. In the light of the recent sounding work of the Discovery $I I^{8}$ and the establishment of an arcuate connexion between South America and Graham Land, it scems quite probable that this well defined submarine ridge exerts a considerable influence on the main body of water flowing away from the Weddell Sea. This ridge comprises the sector of the Scotia Arc between the South Sandwich Islands and Graham Land by way of the South Orkneys. Since it lies in the region of the West Wind Drift, there are thus two strong forces assisting to push the Weddell Sea water to the east. The northerly movement of the Deutschland, which followed her easterly set, can probably be explained by the statement made earlier in this paper that in summer there is also a northerly component of the drift in some places, and this may well have commenced by October igr2.

Hydrological observations also show that a very small proportion of Weddell Sea surface water continues northward near the Graham Land coast and eventually flows westward round Trinity Peninsula into Bransfield Strait.

The influence of the long eastern coast of Graham Land on the Weddell Sea pack moving generally to the west must also be to force it to the north and north-west and to cause serious congestion, which becomes more severe as land is approached. The loss of the Endurance and the escape of the Deutschland can perhaps be regarded as proof of this, for although the Deutschland experienced a certain amount of pressure, it was obviously by no means so severe as that exerted on the Endurance 120-150 miles to the west. Evidence of this pressure is often seen in the pack ice met with off South Georgia early in the summer, when heavy floes and rafted ice have been seen as far north as $50^{\circ} \mathrm{S}$., in about $30^{\circ} \mathrm{W}$. In general it may be said that pack ice of Weddell Sea origin is heavy and irregular and usually shows signs of pressure. Ross Sea pack ice is also heavy, but shows little sign of pressure. Tabular floes rising $10 \mathrm{ft}$. $(3 \mathrm{~m}$.) above the surface are common.

It is also of interest to compare the rate of drift of the pack in the Weddell Sea with that of the Ross Sea. The Endurance in the more closely packed ice near the Graham Land coast averaged 4 miles a day, whereas the drift of the Deutschland was at the rate of 6 miles a day. No other data are known of the rate of drift in the Weddell Sea. When these figures are compared with the Aurora's rate of 2.8 miles a day in the Ross $\mathrm{Sea}^{9}$ it can surely be assumed that the rate of movement of the Weddell Sea pack is almost twice that of the pack ice in the Ross Sea.

If the distribution of the pack in winter is compared with the extent of the East Wind Drift, it would appear almost certain that this current has a considerable influence on the distribution and limits of ice around Antarctica. In the regions where the current is confined to a narrow coastal strip the belt of pack ice is narrow. In the zone of influence of the Weddell Sea currentwhich has its origin in the East Wind Drift - the northerly limit of ice agrees closely with the northern limit of the cold water. The influence of this cold Weddell Sea surface water can be traced to about $35^{\circ} \mathrm{E}$. and it is significant that at this point the ice edge begins to bend towards the south. In the Pacific sector, close to Graham Land and south of Peter I Øya, where the westerly drift is at its minimum, the most stagnant ice conditions occur. Elsewhere, as has already 
been mentioned, it is probable that in most years a large part of the coast of the continent is free from ice in the late summer or early autumn.

Some indication has now been given of the distribution and movement of the Antarctic pack ice, but there are one or two points of general interest to which reference may be made. So far no mention has been made of any of the signs by which a ship steaming southwards may be warned of the proximity of pack ice, nor has anything been said about navigation in the ice itself. The latter subject can be more appropriately dealt with by the professional sailor, but the presence of "ice" or "water" skies can be of great assistance to the navigator. With regard to the proximity of pack ice there are several good indications of its near presence. For instance, changes in the bird life are most marked over a considerable distance north of the pack. Although with most species there are seasonal variations, the Snow Petrel (Pagodroma nivea) never ranges further than 100 miles from the ice edge. Perhaps the most definite indication of pack is the abrupt drop of $\mathrm{I}^{\circ}-\mathrm{I} \cdot 5^{\circ} \mathrm{C}$. in the surface temperature, which usually occurs about $10-20$ miles north of the ice edge. The amount of this drop varies but little throughout the year, although the surface temperature at the ice edge is naturally higher in summer than in winter. In winter the drop is from $0^{\circ}$ or $-0.5^{\circ} \mathrm{C}$. to $-\mathbf{I} \cdot 5^{\circ} \mathrm{C}$. or even lower. Surface temperatures of $-\mathbf{I} \cdot 8^{\circ} \mathrm{C}$. were recorded south of Cape Town on several occasions in the winter of 1938 .

In conclusion it should be remembered that to discuss every aspect of the Antarctic pack ice would occupy much more space than is at my disposal. The broader implications of the distribution and movement have perhaps been adequately indicated, but no reference has been made to such specific problems as the rate of melting and dispersal of the ice, nor to the possible connexion between the northern limit of pack ice and the Antarctic Convergence. The melting and dispersal of pack is a problem of great complexity (see Fig. 5, p. 173). Many observations will be required for various months and these will have to be correlated with meteorological and hydrological observations. The Antarctic Convergence, ${ }^{5}$ which may be described simply as the point where the northward-flowing cold Antarctic water sinks below the less dense sub-Antarctic water, has been determined with some accuracy. It is continuous around Antarctica, and it is almost certain that it must be related in some way to the northern limit of ice. Many other points remain to be elucidated, and, as in the case of the melting and dispersal of the pack ice, numerous hydrological and meteorological observations in all seasons will be required from various points around the continent. If both these can be provided-and one is of little use without the otherwe shall have gone a long way towards a fuller understanding of the problem of the Antarctic pack ice.

From a Paper read at a Meeting of the Society on ${ }_{13}$ November 1947

\section{RE F E RENCES} 1. Hansen, H. E. Limits of the Pack-Ice in the Antarctic in the area between $40^{\circ} \mathrm{W}$. and $110^{\circ}$ E. Hvalradets Skrifter,
Oslo, Nr. 9, 1934 , p. $39-41$, pl. iv-vii. 2. Hansen, H. E. (Ed.). Atlas over Antarktis og Sydishavet. Utgitt av Hvalfangernes Assuranceforening i Anledning av
Foreningens 25-Ars Jubileum. [1936]. 3. Mackintosh, N. A. and Herdman, H. F. P. Distribution of the Pack-Ice in the Southern Ocean. Discovery Reports
(Cambridge), Vol. 19, 1940, p. 285-96, pl. lxiv-xcv.

4. Wordie, J. M. Shackleton Antarctic Expedition, 1914-17: The Natural History of Pack-Ice as observed in the Weddell Sea. Trans. Roy. Soc. Edinbrugh, Vol. 52, Part 4 (No. 31), 1921, p. 795-829, pl. i-iv.

5. Mackintosh, N. A. The Antarctic Convergence and Distribution of Surface Temperatures in Antarctic Waters. Discovery Reports (Cambridge), Vol. 23, 1946, p. 177-212, pl. i-xiv.

6. Deacon, G. E. R. The Hydrology of the Southern Ocean. Discovery Reports (Cambridge), Vol. 15, 1937, p. 1-214,
pl. i-xliv.

7. Brennecke, Wilhelm. Die Ozeanographischen Arbeiten der Deutschen Antarktischen Expedition, 1911-12. Archiv der Deutschen Seewarte, XXXIX. Hamburg, 1921. 8. Herdman, H. F. P. Report on Soundings taken during the Discovery Investigations, 1926-32. Discovery Reports
(Cambridge), Vol. 6, 1932, p. 205-36, pl. xlv-xlvii, charts $1-7$.

9. Wordie, J. M. The Ross Sea Drift of the "Aurora" in 1915-16. Geog. Journ., Vol. 58, 1921, p. 2 19-24. 


\section{I S C U S S I O N}

The Chairman (Mr. J. M. Wordie): Mr. Herdman's paper is bound to promote considerable discussion, but before calling on speakers I should personally like to say a word about the wonderful photographs, which must bring back very pleasant memories to many of us.

Mr. D. Dilwyn John (British Museum, Natural History): Mr. Herdman showed one picture of the pack with leads occupied by newer and darker ice in the Weddell Sea. I was there, and expected Mr. Herdman to say rather more than he did about this. I would like to know if the following is significant : we were in difficulties and were making our way out through this lead, and when we charged we found it quite different from the other ice we had experienced. There was no jar whatever on striking that ice. What is the cause of this difference?

Mr. Herdman: I think that is a question which is answered by the paper written by $\mathrm{Mr}$. Wordie on the subject of pack ice. It is probably due to the formation of ice crystals to a certain depth and the formation of a certain amount of sludge. The one form of ice was true pack and the other was in the early stages of formation.

Commander C. Frankcom, R.N.R. (Meteorological Office, Air Ministry): I am interested in this subject both as a seaman and also as a meteorologist. First let me congratulate the speaker on his excellent photographs, especially those illustrating heavy pack ice. I would like to ask if the speaker is familiar with the maps of the Southern Ice published by the Meteorological Office and Admiralty, which more or less follow the lines of the maps which have been shown us to-night, the data on which go back to 1854 ?

Mr. Herdman : All available maps and data of this region have of course been consulted and I believe that the limits of pack ice as now shown on Admiralty Chart No. 124I were based on the published work of the "Discovery" Investigations.

Cdr. Frankcom : I recently saw an American film by a member of Admiral Byrd's Expedition which showed the complete absence of ice in the Bay of Whales and heavy pack outside. I should be interested to know the reason for this ice-free area.

Mr. Herdman : We have not as yet gone into that question fully. It is possibly due to the fact that when the ice melts it disappears very quickly. As there is a considerable drift westwards along the edge of the Ross Shelf Ice and then northwards towards Cape Adare, it is possible that the pack on the southern side of the Ross Sea ice belt breaks up more quickly than on the northern side, where there is less surface current.

Cdr. Frankcom: I was interested in the lecturer's remarks about the drop in temperatures when he approached the pack. What is the reason for this?

Mr. Herdman: In the Antarctic you have a warm, deep current flowing in from the north and being replaced partly by cold diluted water on the surface and partly by a northward movement of water which has been cooled and has sunk to the bottom. On the surface near the pack you have, therefore, an area where low surface temperatures will always be found.

Cdr. Frankcom : Finally I would like to say that I think the paper we have just heard has probably considerable commercial value in view of the importance of whaling at present. It must also have considerable meteorological value, as the whole world is interested in Antarctic meteorology.

Mr. Alan Refce (Falkland Island Dependencies Survey): From the observational point of view I would like to know the quantitative difference between close pack and open pack.

Mr. Herdman : That is more or less left to the eye of the observer and the amount of experience he has. Close pack will stop a ship. 
The Chairman : Is there anyone present with Baffin Bay experience? One of the strangest things is the open water in Smith Sound throughout most of the year. It might explain the Bay of Whales.

Dr. J. N. Carruthers (Hydrographic Department, Admiralty): In connexion with the American film mentioned by Cdr. Frankcom, I think that the points raised in a Conference on ice problems recently held in the U.S.A. might well interest Mr. Herdman. I shall be pleased to show him relevant papers when next he visits the Hydrographic Department.

The Chairman : Perhaps Commander Burgess would like to contribute?

Commander C. R. Burgess, R.N. (Royal Meteorological Society) (partly communicated): I should like to add to those of others here to-night my congratulations to Mr. Herdman on his paper, which has such great practical value to navigation. Also on his photographs, some of which show what courage and experience are necessary to take a ship many miles into pack ice of such thickness and density. I have enjoyed listening to this lecture, for my interest during the war years in the Admiralty was necessarily confined to the Northern Hemisphere. My slight knowledge of conditions in the Antarctic is confined to the reference to the ice limits defined in the Discovery Reports in order to prepare Admiralty Chart $124 \mathrm{I}$. Compared with conditions in the Northern Hemisphere, the striking difference lies in the small seasonal change of ice limits in the Antarctic. It appears from what we have been told this evening that, in certain sectors at any rate, the ice edge may be met later (when southward bound) in August than in late summer.

I was surprised to hear of air temperature as low as $-15^{\circ} \mathrm{C}$. for ice formation in its early stages. This presumably must apply to locations near the mainland or very near to fairly close and extensive pack, since on the Barents Sea, for example, the lowest temperature recorded, so far as I am aware, during the war was $-12 \cdot 2^{\circ} \mathrm{C}$. except when close to the mainland with an unusually cold off-shore wind. I would have thought that as long as air temperature remained below freezing-point, ice would form provided you have quiet weather conditions.

Mr. Herdman : It probably would in quiet weather conditions, but in the Antarctic everything usually happens by extremes. You get mild weather and then sudden changes to low temperatures, especially in the higher latitude near the continent. At other times of the year you get ice forming at lower temperatures. The ice mentioned in the instance quoted was in March and April. The positions were in nearly $70^{\circ} \mathrm{S}$., close to the Antarctic continent or to an extensive field of heavy pack in the Bellingshausen Sea. The lowest temperature recorded was, I think, in $59^{\circ} \mathrm{S}$. in the meridian of Greenwich, when, in June 1936 , new ice was forming rapidly. No signs of new ice were seen a few miles further north when the temperature was about $-9^{\circ} \mathrm{C}$. In the particular photograph you saw, the air temperatures were about $-10^{\circ}$ and $-8^{\circ} \mathrm{C}$. respectively and the formation of new ice was proceeding rapidly. It had not been noticed earlier in the day.

Cdr. Frankcom: Is not that question related more to the temperature of the water? If the water is down to about the ideal temperature, a slight diminution of air temperature below that point will cause sea ice to form if you have reasonably still weather conditions. On the other hand I have seen off Nantucket an air temperature at sea of $-23^{\circ} \mathrm{C}$. and yet there was no suspicion of ice forming on the sea (still water conditions) because the sea water had not had time to cool sufficiently. The air alone cannot be the influencing factor.

Mr. Herdman : It is the combination of low water temperature and air temperature.

Mr. H. H. Lamb (Meteorological Office, Air Ministry): As I was in the far south myself this last whaling season, having been sent by the Meteorological Office on the Floating Factory Balaena, perhaps our experience in that ship of the formation of new pancake ice may be of interest to Cdr. Burgess and others. We observed rapid formation of new ice about the end of March 1947 when the weather became still, although the air temperature was not lower than 
about $-5^{\circ} \mathrm{C}$. The surface water had been at about its freezing point for some time previously. Later the young ice broke up again completely when the wind freshened.

I would like to ask a question in relation to Mr. Herdman's remarks on irregular variations of the ice edge in the Atlantic sector during the winter season. He stated, I believe, that near the Greenwich meridian the ice edge was found in one season to be much further south in August than in some summer months. How far, therefore, would Mr. Herdman attribute this to higher temperatures in northerly winds and how far to northerly storms and swell, perhaps only one northerly storm, breaking up the ice?

Mr. Herdman : All our logs were handed to the Meteorological Office and we have not been able to refer to them again. I think I can cover the point generally by saying that the period of northerly winds is relatively greater in the latitudes concerned than further south, and while it may be that one northerly gale broke up the ice, it seems unlikely that this was the case. The retreat of the ice edge was nearly 100 miles and it seems probable that a persistence of northerly winds would be required to cause such a displacement.

Mr. LAMB : The wind has to be strong?

Mr. Herdman : Yes. In July of that season we were out for 28 days from Cape Town to the ice edge, and the wind blew at gale force for 24 out of those 28 days. There was also a persistent swell.

Mr. LAMB : Is there any support for my suspicion, based on my meteorological chart work during last season, that warm air reaches high latitudes more particularly in certain longitudes? These are roughly located:

(i) in the eastern part of the Atlantic sector;

(ii) in the eastern part of the Indian Ocean sector, about $80^{\circ}$ to $100^{\circ} \mathrm{E}$.;

(iii) in the Australian sector; and

(iv) just west of Graham Land in the Bellingshausen Sea area.

At least two of these groups of longitudes, namely the Bellingshausen Sea and the Australian sector, are points where the pack ice is particularly far south (i.e. the pack ice belt is unusually narrow). I wonder if my suspicion that these are sectors associated with higher air temperatures than elsewhere is correct ?

Mr. Herdman: We have not yet been able to work up the limited data we possess on this question and it is difficult to do so without the meteorological logs. In the sectors in which you were working, the land is much further north and the pack ice edge is further north also. I think you will find higher air temperatures there, but in the Bellingshausen Sea it does not appear that higher air temperatures can be related to the narrow ice belt. The stagnant ice conditions there are more likely due to the lack of surface current and, if there were a prevalence of higher air temperatures here, I think it might reasonably be expected that a complete break-up would occasionally occur with access to the coast of Antarctica. No such condition is known.

Cdr. FrankCOM : I would like to say on behalf of the Meteorological Office that Mr. Herdman has only to apply to them for the logs he has mentioned and they will gladly be lent to him.

The Charrman : That concludes the discussion to-day. I should like to thank Mr. Herdman for his most interesting paper and I hope we may have a chance of discussing this subject again in the not too distant future. 


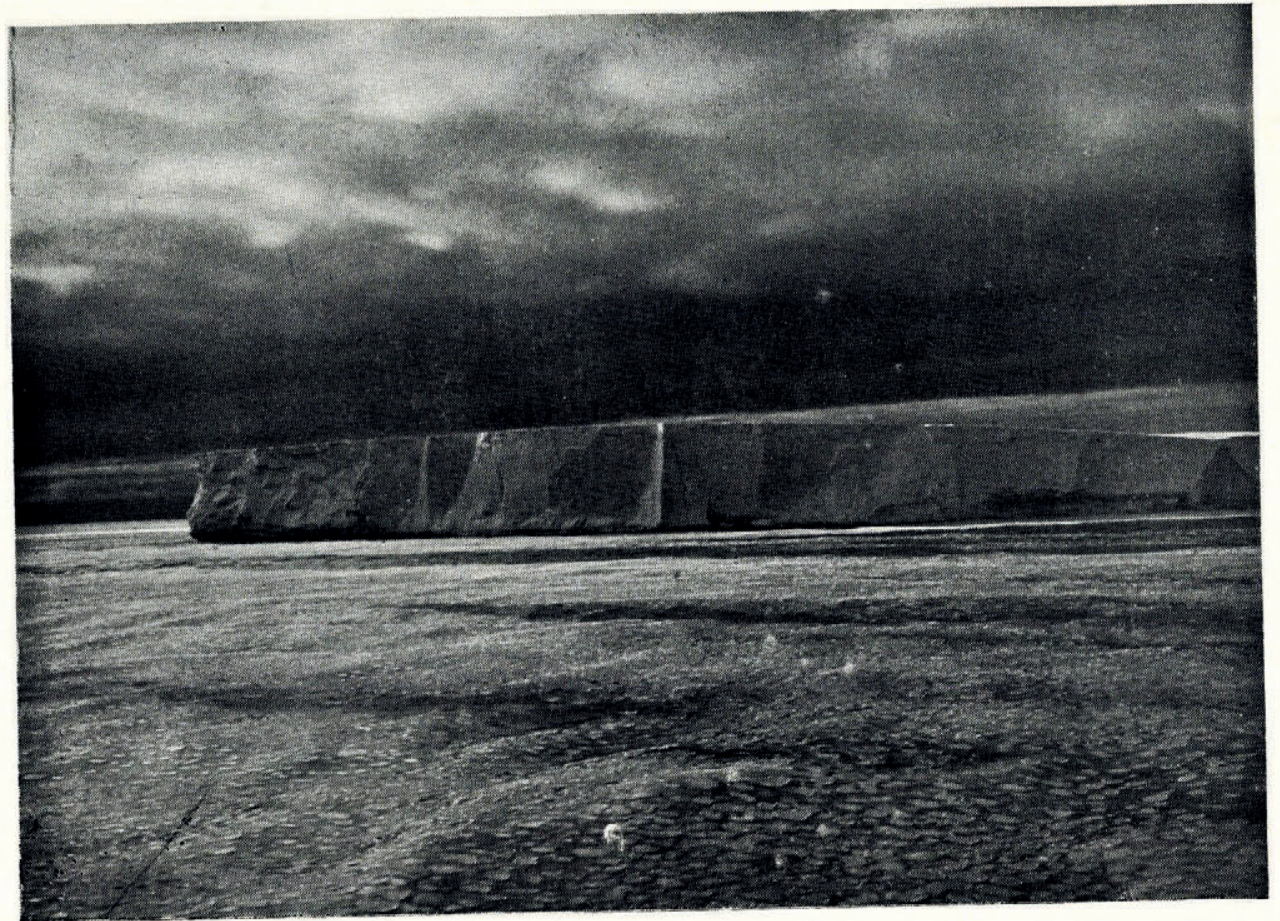

Fig. 2. New ice forming in $70^{\circ}$ S., $4^{\circ}$ E. 3 March 1939. (See p. 159)

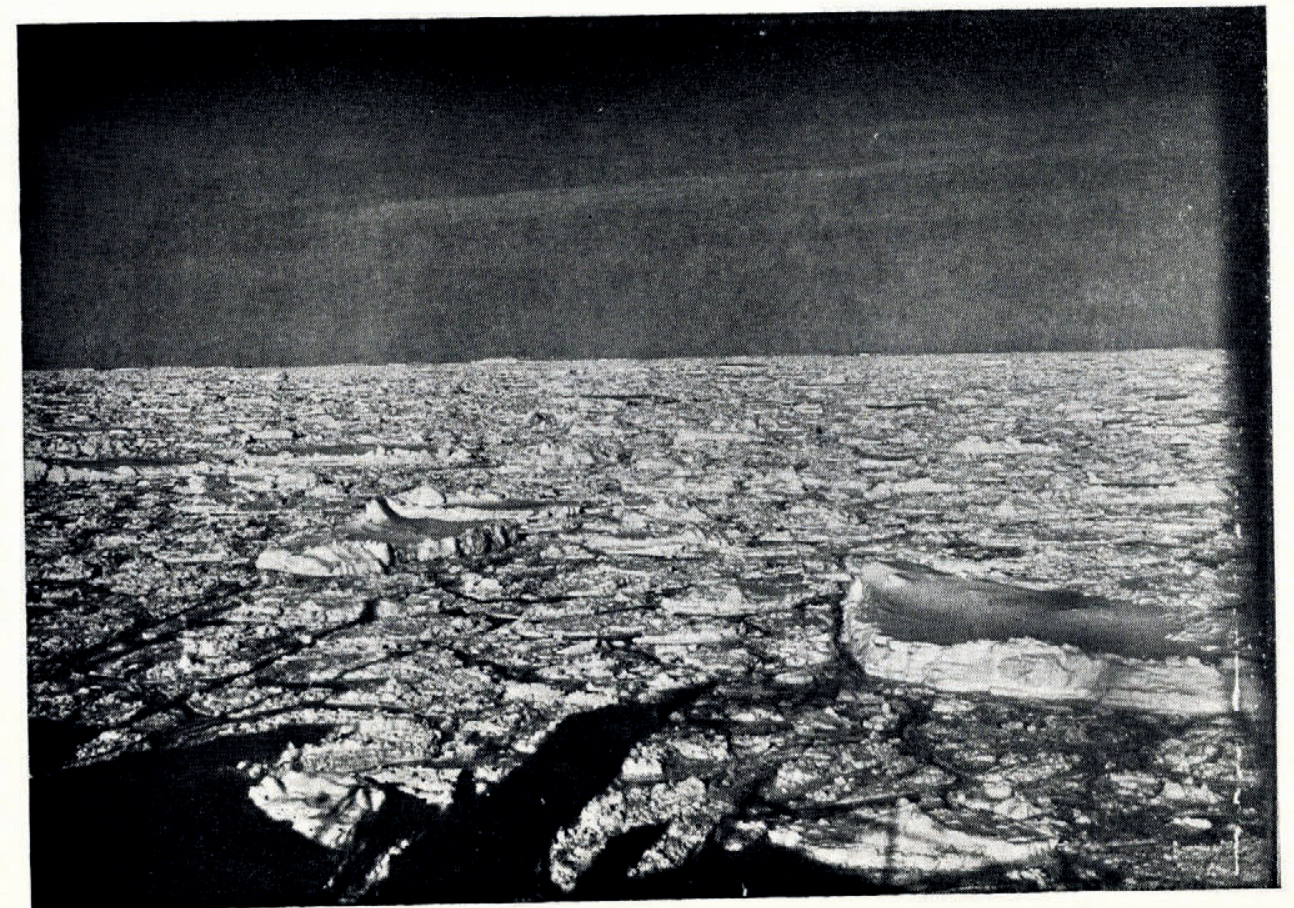

Fig. 3. Pancake Ice off Australian Antarctic Territory ( $64 \frac{1}{2}^{\circ}$ S., $127^{\circ}$ E.) 20 March 1939. Note hard ice sky. (See p. 159) 


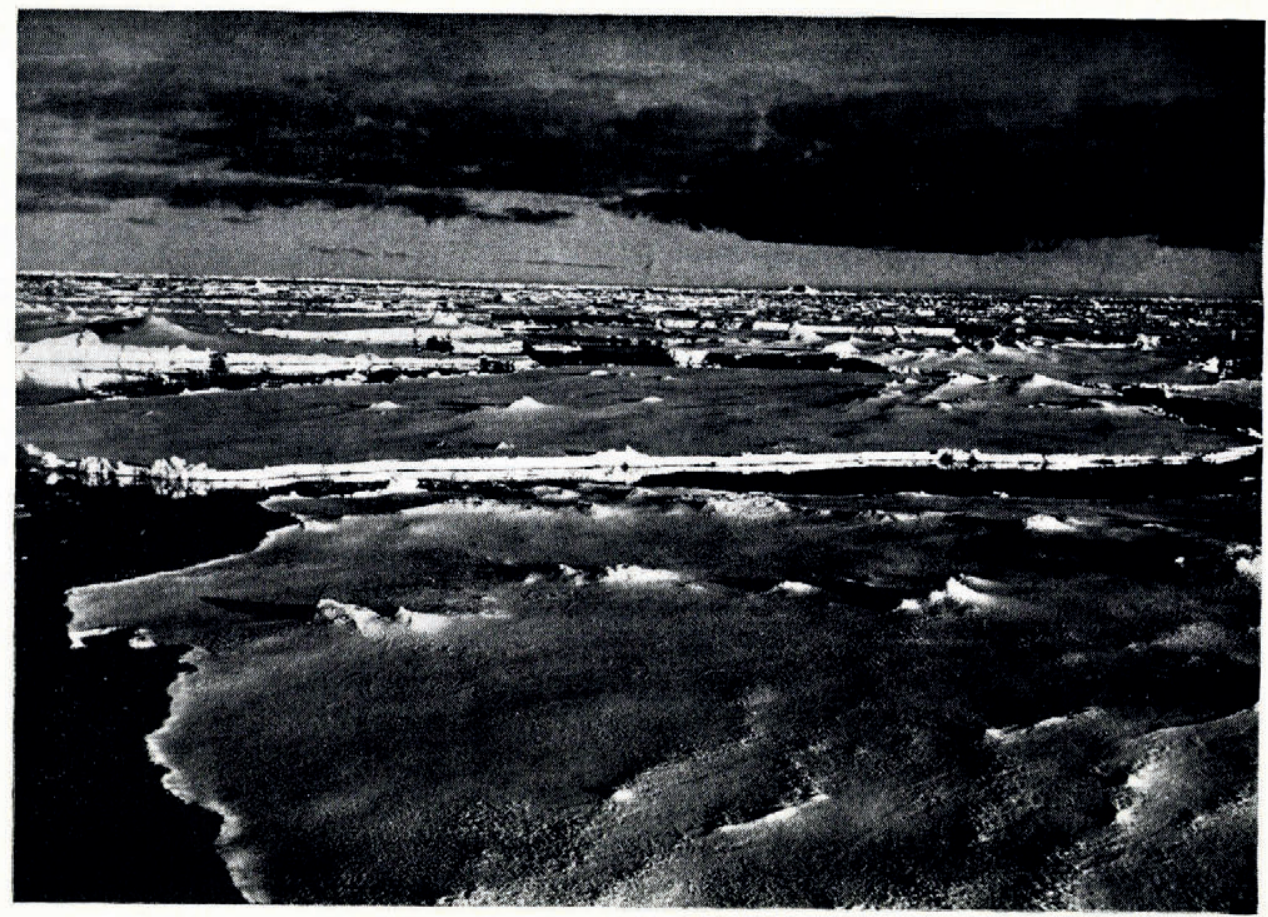

Fig. 4. Very heavy Pack Ice in the Bellingshausen Sea $\left(69^{\circ} 49^{1^{\prime}}\right.$ S., $101^{\circ} 15^{\left.\frac{1^{\prime}}{2} \text { W. }\right)} 6$ Fanuary 1931. Note hard ice sky. (See page 160)

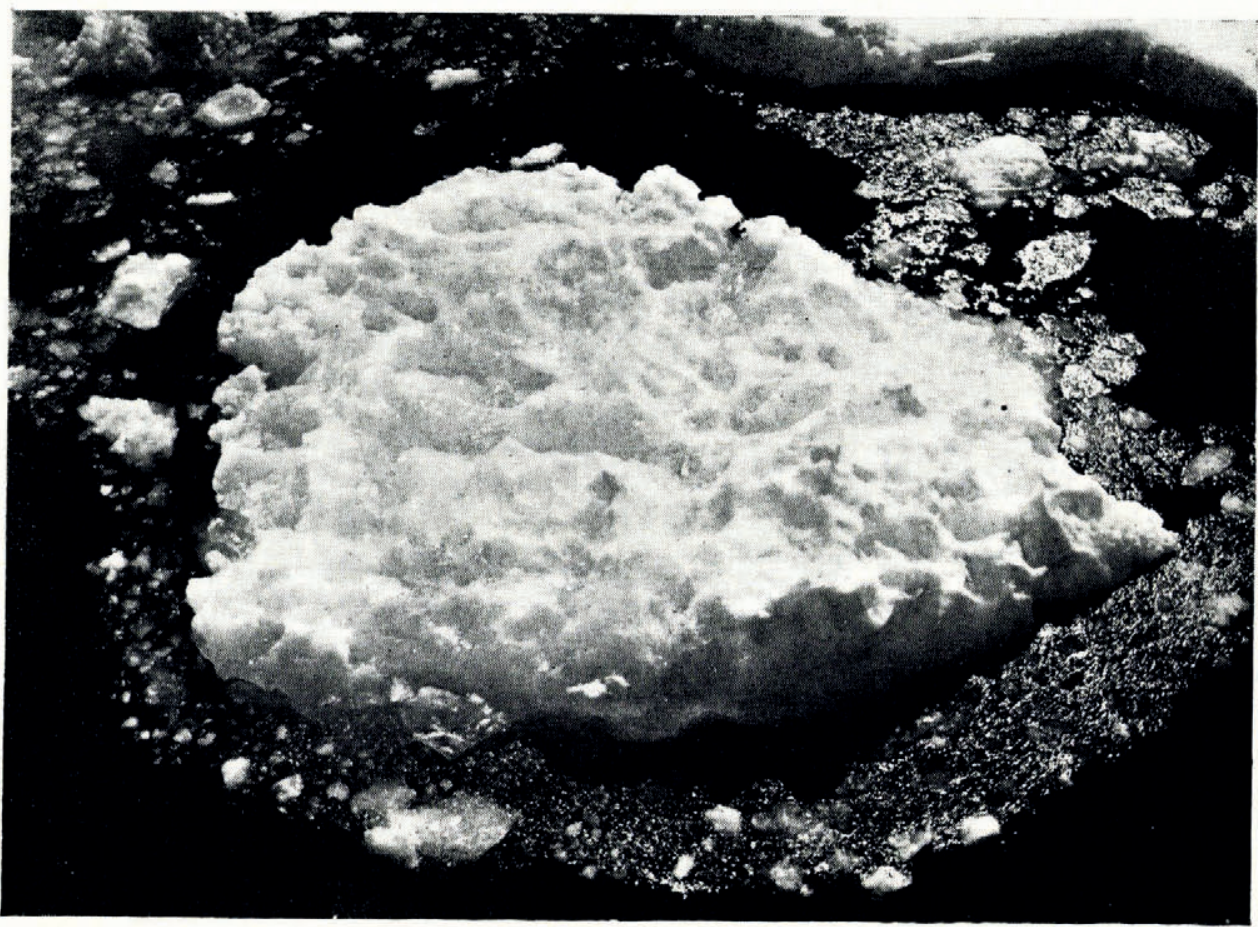

Fig. 5. Melting Pack Ice (inside the pack), Bellingshausen Sea. Fanuary 1931. (See p. 163) 